\title{
Occurrence and ecological risk assessment of heavy metals in agricultural soils of Lake Chilwa catchment in Malawi, Southern Africa
}

\author{
Chisomo Mussa ${ }^{1} \cdot$ Timothy Biswick $^{2} \cdot$ Wisdom Changadeya $^{4} \cdot$ Harold Wilson Mapoma $^{3} \cdot$ Annett Junginger $^{5}$
}

Received: 7 May 2020 / Accepted: 14 October 2020 / Published online: 28 October 2020

(c) Springer Nature Switzerland AG 2020

\begin{abstract}
Understanding the levels and associated ecological risk caused by heavy metals is important for the sustainable management and utilization of Lake Chilwa catchment, an important ecosystem in Malawi providing fertile lands for agriculture and a designated wetland ratified by the Ramsar convention in 1997. Concentrations of chromium (Cr), copper (Cu), nickel $(\mathrm{Ni})$, lead $(\mathrm{Pb})$, zinc $(\mathrm{Zn})$, arsenic $(\mathrm{As})$, mercury $(\mathrm{Hg})$ and cadmium $(\mathrm{Cd})$ were analyzed from 22 soil sampling locations. Extraction and quantification were achieved by microwave digestion and Inductively Coupled Plasma Optical Emission Spectrometer, respectively. Mean values were detected in the following order; $\mathrm{Zn}>\mathrm{Cr}>\mathrm{Ni}>\mathrm{Cu}>\mathrm{Pb}>\mathrm{As}$. Strong correlations were observed between $\mathrm{As}$ and $\mathrm{Pb}(r=0.85), \mathrm{Cr}$ and $\mathrm{Ni}(r=0.82), \mathrm{Cu}$ and $\mathrm{Ni}(r=0.81), \mathrm{Cr}$ and $\mathrm{Cu}(r=0.8)$, and $\mathrm{Pb}$ and $\mathrm{Zn}(r=0.73)$ suggesting similar sources of input. Principal component analysis revealed that $\mathrm{Cu}, \mathrm{Pb}, \mathrm{Zn}$ and $\mathrm{As}$ originate from anthropogenic activities, while $\mathrm{Cr}$ and Ni were geogenic. The ecological risk caused by these metals, calculated by the Ecological Risk Index (RI) method, showed a low to moderate ecological risk. The wetland areas had higher overall concentrations and RI values compared to the rest of the catchment. It is therefore important to enforce measures to manage and control these levels to avoid their damaging effects.
\end{abstract}

Keywords Heavy metals $\cdot$ Soil pollution $\cdot$ Ecological risk $\cdot$ Soil $\cdot$ Lake Chilwa catchment $\cdot$ Malawi

\section{Introduction}

Soil pollution by heavy metals is an important environmental concern causing grave and irreparable damage to ecosystems. Rapid population growth, high urbanization rates, poor planning of cities, poor agricultural practices and lack of enforcement of environmental laws and regulations, among others, have been consistently associated with the accumulation of heavy metals in soils [1,2]. Studies have been carried out to understand the levels of the metals in agricultural soils within the African continent.
Elevated levels of $\mathrm{Cd}, \mathrm{Cr}, \mathrm{Cu}, \mathrm{Ni}, \mathrm{Pb}$ and $\mathrm{Zn}$ in agricultural soils have been reported in Egypt [3], Nigeria [4], Kenya $[5,6]$, South Africa [7] and Zambia [8]. The concentrations were mainly attributed to mining activities, waste disposal, application of organic manure, inorganic fertilizers, herbicides and pesticides. Heavy metals accumulate in surface soils and migrate to crops by plant root respiration. Humans and animals are exposed directly or indirectly through consumption of contaminated food plants [9, 10]. Some metals such as $\mathrm{Zn}$ and $\mathrm{Ni}$ are essential for cell metabolic processes and are required within specified

$\triangle$ Chisomo Mussa, mussachisomo@gmail.com | 1 Department of Environmental Science and Management, Faculty of Natural Resource Management, Lilongwe University of Agriculture and Natural Resources, Lilongwe, Malawi. ${ }^{2}$ Department of Chemistry, Faculty of Science, Chancellor College, Zomba, Malawi. ${ }^{3}$ Department of Physics and Biochemical Sciences, The Polytechnic, Blantyre, Malawi. ${ }^{4}$ Department of Biology, Faculty of Science, Chancellor College, Zomba, Malawi. ${ }^{5}$ Department of Geosciences, Faculty of Mathematics and Natural Sciences, University of Tübingen, Tübingen, Germany. 
amounts. Other heavy metals such as $\mathrm{Pb}, \mathrm{Cd}, \mathrm{Hg}$ and $\mathrm{As}$ have no beneficial effects in plants and animals and are considered toxic [11].

To the best of our knowledge, limited studies have been carried out on heavy metals in Malawi, mostly on the levels of heavy metals in surface water from different parts of the country. For example, $\mathrm{Cu}$ and $\mathrm{Pb}$ were detected in Mudi River, a river that passes through the industrial areas of Blantyre, the commercial city of Malawi [12]. Another study reported on the presence of $\mathrm{Cr}, \mathrm{Pb}$ and $\mathrm{Zn}$ in the waters of Likangala River, which passes through Zomba city, the old capital of Malawi [13]. A recent study about Lake Chilwa, reported on the presence of $\mathrm{Cu}$ and $\mathrm{Zn}$ in the sediments of the lake and attributed this to fertilizer usage and indiscriminate disposal of metal products within the catchment [14]. Our previous study also reported the presence of $\mathrm{Pb}$, $\mathrm{Zn}, \mathrm{Cu}, \mathrm{Cd}, \mathrm{Cr}$, and $\mathrm{Ni}$ in Lake Chilwa and influent rivers [15]. The only study that has reported on heavy metals in soils was carried out in riverbank soils along Mudi River, which passes through the industrial area of Blantyre city. The results showed the following average concentrations; $\mathrm{Cr}(8.19 \mathrm{mg} / \mathrm{kg}), \mathrm{Cu}(10.13 \mathrm{mg} / \mathrm{kg}), \mathrm{Ni}(4.32 \mathrm{mg} / \mathrm{kg}), \mathrm{Pb}$ (3.49 $\mathrm{mg} / \mathrm{kg}), \mathrm{Zn}(17.45 \mathrm{mg} / \mathrm{kg})$ and $\mathrm{Cd}(0.18 \mathrm{mg} / \mathrm{kg})$ and this was attributed to industrial effluents [16].

Lake Chilwa catchment is an important ecosystem in Malawi providing ecosystem services beneficial to all forms of life. However, intensification of agricultural enterprises coupled with improper farming practices, insufficient waste management facilities and lack of enforcement of environmental laws and regulations have the potential to elevate the concentrations of heavy metals to toxic levels in agricultural soils of the catchment. This research was therefore carried out to determine the concentrations of heavy metals in the agricultural soils, identify the possible sources and to evaluate their ecological risk. The study is significant as it informs communities and policy about the ecological risks associated with levels of the studied elements in the area. It further adds valuable data to our basic knowledge that are needed to understand the area and stimulate future research on soils and related segments of the catchment. Also, the results will be useful to formulate holistic management strategies for the sustainable utilization and conservation of this important catchment and provide a baseline for future research.

\subsection{Setting}

Lake Chilwa catchment is located in the southern part of Malawi bordering Mozambique to its eastern side (Fig. 1). The catchment covers three districts, namely Machinga, Zomba and Phalombe. Main crops grown in the catchment are maize and rice. Other crops include cassava, groundnuts, millet, sweet potatoes, vegetables, sugar cane and bananas. The common practice of farming, especially for

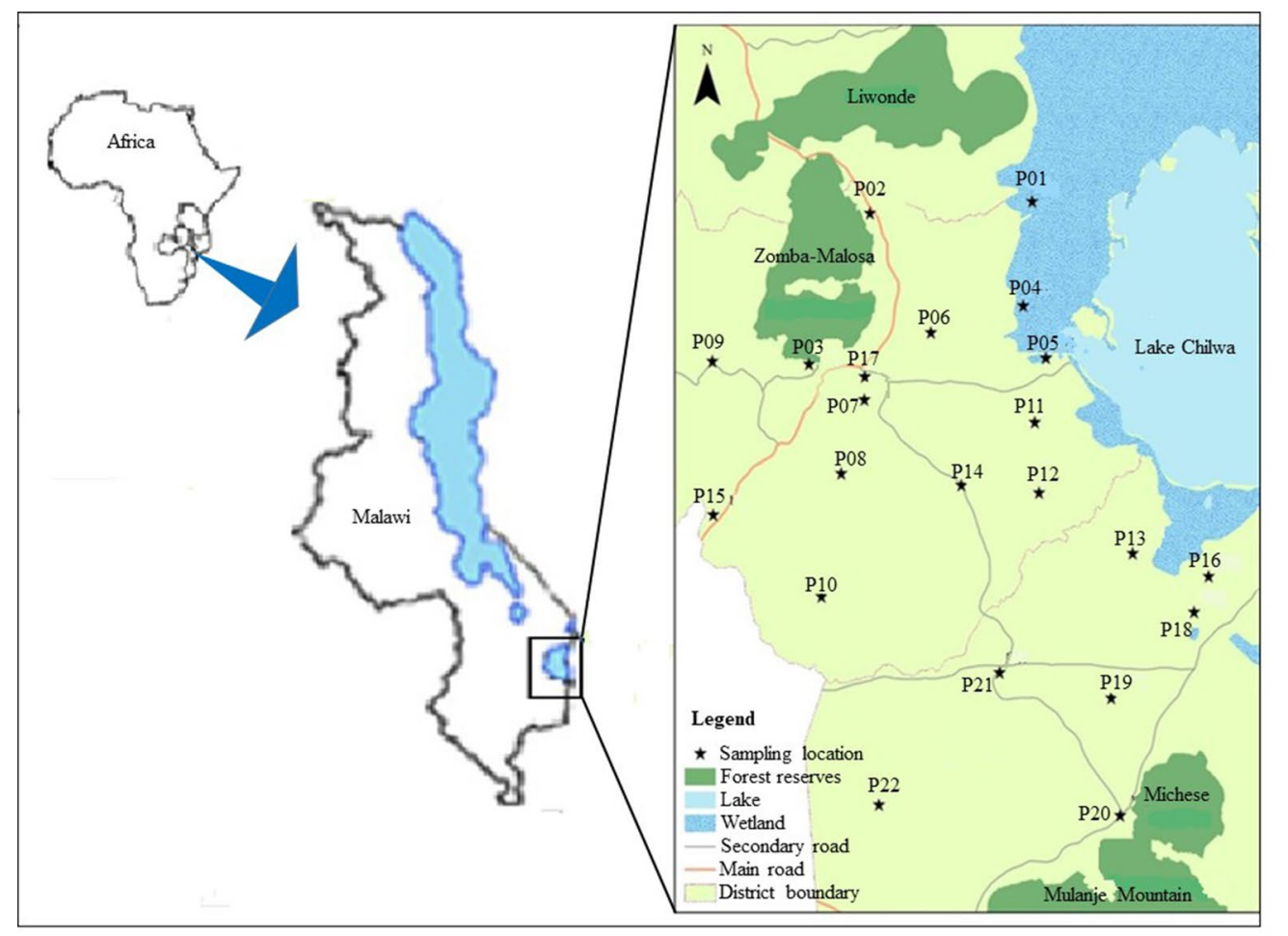

Sampling points and their coordinates
\begin{tabular}{|lll|}
\hline & & \\
ID & Easting & Northing \\
\hline P01 & 773054 & 8316136 \\
P02 & 754122 & 8314874 \\
P03 & 747010 & 8298799 \\
P04 & 772002 & 8304987 \\
P05 & 774690 & 8299439 \\
P06 & 761249 & 8302157 \\
P07 & 753503 & 8294947 \\
P08 & 750778 & 8287117 \\
P09 & 735742 & 8299096 \\
P10 & 748443 & 8273958 \\
P11 & 773388 & 8292543 \\
P12 & 773895 & 8285071 \\
P13 & 784795 & 8278605 \\
P14 & 764787 & 8285853 \\
P15 & 735821 & 8282690 \\
P16 & 793693 & 8276134 \\
P17 & 753507 & 8297430 \\
P18 & 791991 & 8272335 \\
P19 & 782309 & 8263128 \\
P20 & 783360 & 8250630 \\
P21 & 769272 & 8265861 \\
P22 & 755191 & 8251776 \\
\hline
\end{tabular}

Fig. 1 Map of the Chilwa catchment located in Malawi within the Southern African region showing the sampling points

\section{SN Applied Sciences}


maize, is the ridge and furrow system using a hand hoe. The wetland area close to the lake constitutes fertile soils and is dominated by rice and maize fields.

Most of the Chilwa basin is underlain by ancient metamorphic and igneous rocks of the Malawi Basement complex represented by a group of high-grade metamorphic rocks, mostly chamokitic granulites of quartz and feldspar. South of the Lake, there is a complex of alkaline silicate rocks, carbonates, rocks rich in sodium and calcium carbonates. Major soil groups include calcimorphic alluvial soils, hydromorphic soils, latosols and lithosols (young 1960).

\section{Materials and methods}

\subsection{Sampling and heavy metal extraction}

A total of 22 soil samples were purposively sampled in the dry season (Fig. 1). The samples represent the different parts of the catchment including, the upland fields ( $\mathrm{P03}$ and P02), wetland fields (P01, P04, P05, P18 and P13), semi intensive fields within estates and farmer schemes (P08, $\mathrm{P} 10, \mathrm{P} 11$ and $\mathrm{P} 15)$, fields within the city and towns (P14, $\mathrm{P} 21, \mathrm{P} 17$ and $\mathrm{P} 20)$ and fields located in the rural areas (P06, P07, P09, P12, P16, P19 and P22). The soil samples were collected from a depth of $0-10 \mathrm{~cm}$ using a stainless-steel shovel and stored in polyester bags. The samples were dried and ground to powder using a pestle and mortar before sieving them through a 60-mesh. Heavy metal extraction was achieved by the aqua regia microwave digestion method where $1 \mathrm{~g}$ of the sample was placed in a Teflon digestion tube together with $10 \mathrm{~mL} \mathrm{HNO}_{3}$ and $3 \mathrm{~mL}$ $\mathrm{HCl}$. The solution was filtered through a $0.45 \mu \mathrm{m}$ membrane and the concentrations of the heavy metals were determined on Inductively Coupled Plasma Optical Emission Spectrometer (ICP-OES) at the University of Tubingen in Germany. Blanks and standards were also performed for quality control.

\subsection{Potential ecological risk index of heavy metals}

The ecological risk index (RI) was used to quantify the potential environmental and human health hazard from heavy metal contamination in the soils. The RI represents the toxicity of heavy metals and the response of the environment [17].

The potential ecological risk is defined as follows:

$C_{f}^{i}=C_{\text {surface }}^{i} / C_{\text {reference }}^{i} C_{f}^{i}=C_{\text {surface }}^{i} / C_{\text {reference }}^{i}$

$E_{f}^{i}=C_{f}^{i} \times T_{f}^{i} E_{f}^{i}=C_{f}^{i} \times T_{f}^{i}$

$R I=\sum_{f}^{i} E_{f}^{i} R I=\sum_{f}^{i} E_{f}^{i}$

where $C_{f}^{i}$ is the contamination factor that describes the contamination of a given toxic metal in the soil. $C_{\text {surface }}^{i}$ is the measured concentration of heavy metals in soils. $C_{\text {reference }}^{i}$ is the background reference values of the metals in soils (Table 1). $T_{f}^{i}$ is the toxic response factor for a given substance provided by Hakanson, also given in Table 1 . $E_{f}^{i}$ is the potential risk index for a single heavy metal. RI is the sum of individual potential risk factors $E_{f}^{i}$ for heavy metals in soils. The following terminologies are used to describe the risk factor: $\mathrm{RI} \leq 50$ suggest low ecological risk; $50 \leq \mathrm{RI}<100$, moderate ecological risk; $100<\mathrm{RI} \leq 150$, considerable ecological risk; and $\mathrm{RI} \geq 150$, high ecological risk [17].

\subsection{Statistical analysis}

Data entry and statistical analysis were performed using MS Excel (Microsoft 2010) and PAST 3 statistical software. Pearson correlation, Principal Component Analysis (PCA) and Eigenvector analysis were used to determine the relationship among the heavy metals and apportion the sources.

\section{Results and discussion}

Tables 2 and 3 present a summary of results of all metals measured in the soils from all sampling sites. The average concentrations decreased in the following order $\mathrm{Zn}>\mathrm{Cr}>\mathrm{Ni}>\mathrm{Cu}>\mathrm{Pb}>\mathrm{As}$. $\mathrm{Hg}$ and $\mathrm{Cd}$ were not detected from all sampling locations. Due to the absence of standards for heavy metals in soils in Malawi, the United States Environmental Protection Agency standards [18] were used in this study. The average concentrations were all
Table 1 Background reference levels $(\mathrm{mg} / \mathrm{kg})$ and toxic response factors by [17]

\begin{tabular}{|c|c|c|c|c|c|c|c|}
\hline & $\mathrm{Hg}$ & $\mathrm{Cd}$ & As & $\mathrm{Cu}$ & $\mathrm{Pb}$ & $\mathrm{Cr}$ & $\mathrm{Zn}$ \\
\hline $\begin{array}{l}\text { Background refer- } \\
\text { ence levels }\end{array}$ & 0.02 & 0.1 & 12.7 & 22.5 & 21.00 & 67.3 & 65.4 \\
\hline $\begin{array}{l}\text { Toxic response } \\
\text { factor }\end{array}$ & 40 & 30 & 10 & 5 & 5 & 2 & 1 \\
\hline
\end{tabular}


Table 2 Concentration $(\mathrm{mg} / \mathrm{kg})$ of heavy metals and ecological Risk Index (RI) values
Table 3 Summary statistics of heavy metal concentrations in $\mathrm{mg} / \mathrm{kg}$ in comparison with the maximum allowed levels for [18]

\begin{tabular}{lrrrrlllll}
\hline ID & \multicolumn{1}{c}{$\mathrm{Cr}$} & \multicolumn{1}{c}{$\mathrm{Cu}$} & \multicolumn{1}{c}{$\mathrm{Ni}$} & $\mathrm{Pb}$ & $\mathrm{Zn}$ & $\mathrm{As}$ & $\mathrm{Hg}$ & $\mathrm{Cd}$ & $\mathrm{Rl}$ \\
\hline P01 & 26.16 & 20.97 & 16.29 & 16.81 & 99.21 & 5.11 & $\mathrm{BDL}$ & $\mathrm{BDL}$ & 7.89 \\
P02 & 27.90 & 5.70 & 14.53 & 4.11 & 15.21 & $\mathrm{BDL}$ & $\mathrm{BDL}$ & $\mathrm{BDL}$ & 1.58 \\
P03 & 3.12 & 4.08 & 3.83 & 7.00 & 22.92 & $\mathrm{BDL}$ & $\mathrm{BDL}$ & $\mathrm{BDL}$ & 1.11 \\
P04 & 52.04 & 28.92 & 34.14 & 7.52 & 61.47 & 1.36 & $\mathrm{BDL}$ & $\mathrm{BDL}$ & 5.84 \\
P05 & 63.13 & 33.57 & 21.98 & 5.42 & 79.14 & $\mathrm{BDL}$ & $\mathrm{BDL}$ & $\mathrm{BDL}$ & 5.60 \\
P06 & 21.01 & 11.11 & 15.79 & 5.00 & 22.19 & 0.68 & $\mathrm{BDL}$ & $\mathrm{BDL}$ & 2.51 \\
P07 & 31.99 & 8.02 & 17.11 & 4.99 & 13.56 & 0.43 & $\mathrm{BDL}$ & $\mathrm{BDL}$ & 2.34 \\
P08 & 7.11 & 11.98 & 18.20 & 5.66 & 17.01 & 0.27 & $\mathrm{BDL}$ & $\mathrm{BDL}$ & 2.04 \\
P09 & 31.14 & 12.43 & 16.66 & 4.60 & 22.70 & 0.55 & $\mathrm{BDL}$ & $\mathrm{BDL}$ & 2.76 \\
P10 & 8.08 & 13.13 & 15.22 & 5.87 & 16.01 & 0.21 & $\mathrm{BDL}$ & $\mathrm{BDL}$ & 2.14 \\
P11 & 20.62 & 6.36 & 9.14 & 4.25 & 23.48 & 0.72 & $\mathrm{BDL}$ & $\mathrm{BDL}$ & 2.01 \\
P12 & 7.11 & 12.01 & 14.11 & 5.76 & 18.00 & 0.55 & $\mathrm{BDL}$ & $\mathrm{BDL}$ & 2.24 \\
P13 & 31.15 & 33.79 & 43.18 & 8.14 & 60.81 & 2.07 & $\mathrm{BDL}$ & $\mathrm{BDL}$ & 6.38 \\
P14 & 65.87 & 11.26 & 17.66 & 3.37 & 27.51 & $\mathrm{BDL}$ & $\mathrm{BDL}$ & $\mathrm{BDL}$ & 2.99 \\
P15 & 41.20 & 22.57 & 16.53 & 9.29 & 37.12 & 0.92 & $\mathrm{BDL}$ & $\mathrm{BDL}$ & 4.66 \\
P16 & 29.77 & 10.19 & 14.33 & 4.92 & 26.39 & 0.66 & $\mathrm{BDL}$ & $\mathrm{BDL}$ & 2.64 \\
P17 & 2.83 & 4.12 & 2.52 & 8.96 & 92.85 & 4.20 & $\mathrm{BDL}$ & $\mathrm{BDL}$ & 4.44 \\
P18 & 29.09 & 12.15 & 14.68 & 8.87 & 45.13 & 2.25 & $\mathrm{BDL}$ & $\mathrm{BDL}$ & 4.25 \\
P19 & 26.78 & 12.02 & 14.28 & 7.43 & 45.43 & 1.91 & $\mathrm{BDL}$ & $\mathrm{BDL}$ & 3.86 \\
P20 & 3.00 & 5.78 & 4.07 & 6.89 & 21.64 & 0.67 & $\mathrm{BDL}$ & $\mathrm{BDL}$ & 1.71 \\
P21 & 38.84 & 8.99 & 20.05 & 4.56 & 23.74 & 0.51 & $\mathrm{BDL}$ & $\mathrm{BDL}$ & 2.57 \\
P22 & 21.07 & 6.77 & 14.81 & 4.55 & 16.09 & 0.83 & $\mathrm{BDL}$ & $\mathrm{BDL}$ & 2.11 \\
\hline
\end{tabular}

$B D L$, Below detection limit

\begin{tabular}{lrrrrrlll}
\hline & \multicolumn{1}{l}{$\mathrm{Cr}$} & \multicolumn{1}{l}{$\mathrm{Cu}$} & \multicolumn{1}{c}{$\mathrm{Ni}$} & \multicolumn{1}{c}{$\mathrm{Pb}$} & \multicolumn{1}{l}{$\mathrm{Zn}$} & $\mathrm{As}$ & $\mathrm{Hg}$ & $\mathrm{Cd}$ \\
\hline Min & 2.83 & 4.08 & 2.52 & 3.37 & 13.56 & $\mathrm{BDL}$ & $\mathrm{BDL}$ & $\mathrm{BDL}$ \\
Max & 65.87 & 33.79 & 43.18 & 16.81 & 99.21 & 5.11 & $\mathrm{BDL}$ & $\mathrm{BDL}$ \\
Mean & 26.77 & 13.45 & 16.32 & 6.54 & 36.71 & 1.09 & $\mathrm{NA}$ & $\mathrm{NA}$ \\
SD & 18.06 & 8.91 & 8.90 & 2.86 & 25.96 & 1.33 & $\mathrm{NA}$ & $\mathrm{NA}$ \\
CV & 67.45 & 66.21 & 54.50 & 43.77 & 70.71 & 122.52 & $\mathrm{NA}$ & $\mathrm{NA}$ \\
USEPA (2010) & 250.00 & 1500.00 & 420.00 & 300.00 & 2800.00 & 41.00 & 17.00 & 39 \\
\hline
\end{tabular}

$S D$, Standard deviation, $C V$, coefficient of variation, $B D L$, below detection limit, $N A$, not applicable below the threshold limits of USEPA. However, heavy metals are persistent and bioaccumulate and magnify high in the food chain causing health implications to higher trophic level organisms. Therefore, it is of great importance to monitor their levels to avoid detrimental environmental and health effects.

Significant spatial variation was observed in this study. The wetland points, $\mathrm{P} 01, \mathrm{P} 04, \mathrm{P} 05$ and $\mathrm{P} 13$ had the highest levels of $\mathrm{Pb}, \mathrm{Zn}, \mathrm{As}, \mathrm{Cr}, \mathrm{Cu}$ and $\mathrm{Ni}$ as shown in Table 2. The wetland area is dominated by intensive rice and maize fields and therefore application of fertilizers, pesticides and manure in these fields could be attributed to these levels $[19,20]$. Agricultural enterprises, especially within the lower catchment, have increased rapidly, replacing much of the natural vegetation [21]. Figure 2 shows land use change within the catchment, highlighting increased agricultural activities (shown in pink color). It should be noted that there are no industrial activities on a scale that can have significant impacts on the levels of elements in the area apart from agriculture and fishing related activities.

Fields located within the city and trading centers (P14 and P17) showed high levels of $\mathrm{Cr}, \mathrm{Pb}, \mathrm{Zn}$ and As. Vehicular emissions, poor waste management and agrochemicals could be associated with the levels. Fields located in the rural areas and upland sparsely populated mountain areas, dominated by maize subsistence fields (P06, P07, P09, P12, P16, P19 and P22), had the lowest concentrations.

A comparison of heavy metal studies in agricultural soils elsewhere are summarized in Table 4 . The results 
show varied findings across the continent. Levels above our findings were observed from areas with either mining or industrial activities.

The Pearson correlation matrix shows significant positive correlations between $\mathrm{Cr}$ and $\mathrm{Cu}, \mathrm{Cr}$ and $\mathrm{Ni}, \mathrm{Cu}$ and $\mathrm{Ni}, \mathrm{Cu}$ and $\mathrm{Zn}, \mathrm{Pb}$ and $\mathrm{As}$ and $\mathrm{Zn}$ and $\mathrm{As}$ (Table 5). Strong correlations can indicate that each paired element has an identical source [30].

To further pin out the elemental associations and tease out the probable sources, Principal Component
Analysis (PCA) was computed and the results are presented in Table 6 and illustrated in Fig. 3. Two principal components $(P C)$ were extracted, and the cumulative variance contribution rate was $84.17 \%$. PC 1 accounts for $49.27 \%$ of the total variance, while PC 2 accounts for $34 \%$ of the total variance. $\mathrm{Cu}, \mathrm{Pb}, \mathrm{Zn}$, As have high loadings on $P C 1$ suggesting an identical source. These elements are commonly associated with agrochemicals, mainly from pesticides, manure and inorganic fertilizers. $\mathrm{Zn}$ and $\mathrm{Pb}$ have been reported as impurities in inorganic fertilizers
1990

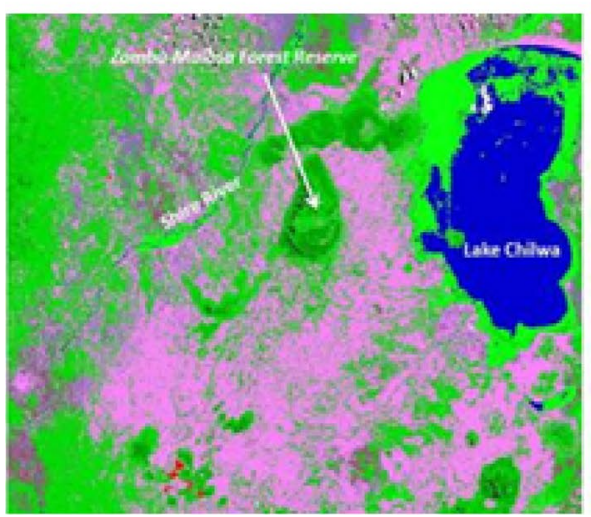

2000

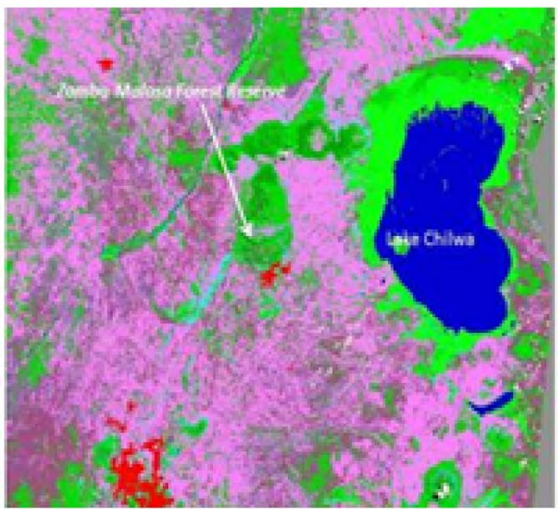

2010

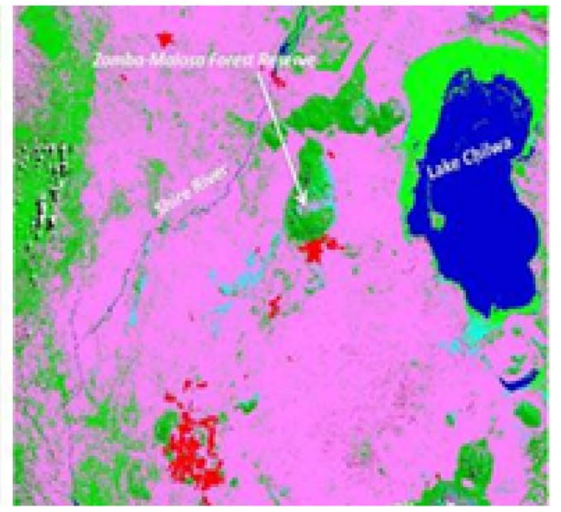

Fig. 2 Intensification of agricultural activities in Lake Chilwa catchment from 1990 to 2010

Table 4 Heavy metals in agricultural soils $(\mathrm{mg} / \mathrm{kg})$ from other studies

Table 5 Correlation matrix of the heavy metals in agricultural soils of Lake Chilwa catchment $(P<0.05)$

\begin{tabular}{llrrllllll}
\hline City/Country & $\mathrm{Cr}$ & $\mathrm{Cu}$ & $\mathrm{Pb}$ & $\mathrm{Zn}$ & $\mathrm{Ni}$ & $\mathrm{Cd}$ & $\mathrm{Hg}$ & $\mathrm{As}$ & Reference \\
\hline Zomba, Malawi & 26.77 & 13.45 & 6.54 & 36.71 & 16.32 & - & - & 1.09 & This study \\
Egypt & 8.42 & 3.82 & 0.24 & 21.87 & 10.28 & 0.09 & - & - & {$[8]$} \\
Lusaka, Zambia & 39.00 & 343.00 & 48.00 & 147.00 & 20.00 & 0.11 & 0.02 & 4.00 & {$[11]$} \\
Nigeria & 0.26 & 20.52 & 15.00 & 27.70 & 0.05 & 0.02 & 0.02 & - & {$[1]$} \\
Kunshan, China & 87.73 & 34.27 & 30.48 & 105.93 & 31.08 & 0.2 & 0.2 & 8.15 & {$[22]$} \\
Spain & 63.48 & 107.65 & 213.93 & 427.8 & 34.75 & 1.42 & - & - & {$[23]$} \\
America & - & 95.00 & 23.00 & - & 57.00 & 0.78 & - & - & {$[24]$} \\
Korea & - & 2.98 & 5.25 & 4.78 & - & 0.12 & 0.05 & 0.78 & {$[25]$} \\
Slovakia & - & 65.00 & 139.00 & 140.00 & 29.00 & - & - & - & {$[26]$} \\
USA & 48.5 & 48.00 & 55.00 & 88.5 & 29.00 & 13.5 & - & - & {$[27]$} \\
India & 2.19 & 1.2 & 0.95 & 28.24 & 4.34 & 0.82 & - & - & {$[28]$} \\
Iran & 10.36 & 9.62 & 5.17 & 11.56 & 11.28 & 0.34 & - & - & {$[29]$} \\
\hline
\end{tabular}

\begin{tabular}{lllllll}
\hline & $\mathrm{Cr}$ & $\mathrm{Cu}$ & $\mathrm{Ni}$ & $\mathrm{Pb}$ & $\mathrm{Zn}$ & $A s$ \\
\hline $\mathrm{Cr}$ & 1 & & & & & \\
$\mathrm{Cu}$ & 0.80 & 1 & & & & \\
$\mathrm{Ni}$ & 0.82 & 0.81 & 1 & 1 & & \\
$\mathrm{~Pb}$ & 0.02 & 0.34 & 0.04 & 0.73 & 1 & \\
$\mathrm{Zn}$ & 0.35 & 0.54 & 0.21 & 0.85 & 0.80 & 1 \\
$\mathrm{As}$ & -0.01 & 0.16 & 0.00 & 0.00 & & \\
\hline
\end{tabular}


Table 6 Matrix of PCA

\begin{tabular}{lrr}
\hline Parameter & PC 1 & \multicolumn{1}{c}{ PC 2 } \\
\hline $\mathrm{Cr}$ & 0.37 & 0.75 \\
$\mathrm{Cu}$ & 0.77 & 0.54 \\
$\mathrm{Ni}$ & 0.53 & 0.72 \\
$\mathrm{~Pb}$ & 0.77 & -0.54 \\
$\mathrm{Zn}$ & 0.90 & -0.24 \\
$\mathrm{As}$ & 0.73 & -0.62 \\
Eigenvalue & 2.96 & 2.09 \\
\% variance & 49.27 & 34.90 \\
\hline
\end{tabular}

[31], Cu and $\mathrm{Zn}$ are highly associated with farmyard manure [32], Lead arsenate (acid- $\mathrm{PbHAsO}_{4}$ or basic$\left.\left.\mathrm{Pb}_{4}(\mathrm{PbOH})\left(\mathrm{AsO}_{4}\right)^{3}\right)\right)$ and $\mathrm{Zn}$ arsenate $\left(\mathrm{As}_{2} \mathrm{O}_{8} \mathrm{Zn}_{3}\right)$ are used as pesticides, especially in vegetable gardens and rice fields $[33,34]$. It follows that application of fertilizers, pesticides and manure in the fields and gardens are a probable source of these elements. As stated earlier, metals and related industrial activities in the area are insignificant compared to agriculture activities. Possible sources of metals are remnants of agricultural tools such as hoes and sporadic remains of old metals from cars and other small materials. As such these may not contribute significant amounts of these elements. Concentrations of Ni did not vary much across the catchment, an indication that the source could be geogenic. Therefore, the second PC with high loadings of $\mathrm{Cr}$ and $\mathrm{Ni}$ could be attributed to leaching and weathering of the parent rock material, more, especially from the igneous rocks. Contribution from various sources including (for $\mathrm{Cr}$ ) vehicular sources such as road dust from catalytic converter erosion and asbestos brakes and (both $\mathrm{Ni}$ and $\mathrm{Cr}$ ) waste incineration are perceived minimal in this area due to low activities of such nature.

The potential Ecological Risk Index ranged from low ecological risk (6.09) at P03 to moderate ecological risk (71.17) at P13 (Fig. 4). The wetland locations (P01, P13, $P 16)$ with intensive cultivation show a moderate ecological risk compared to the rest of the catchment. This is in tandem with the observed levels and the PCA, suggesting a link between intensified agricultural activities and associated levels. There is therefore a need for monitoring and enforcement of measures to control the levels of heavy metals in this catchment and avoid their detrimental effects.
Fig. 3 Two dimensional PCA loading plot for heavy metals in agricultural soils of Lake Chilwa catchment

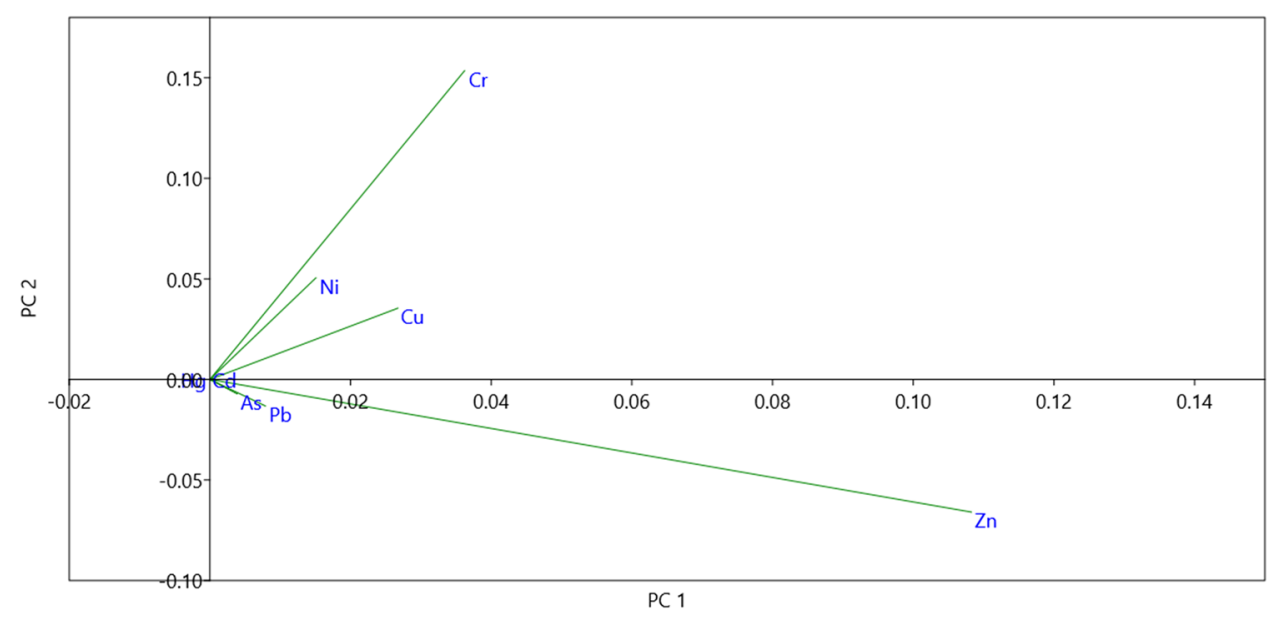

Fig. 4 Potential ecological risk index across the catchment

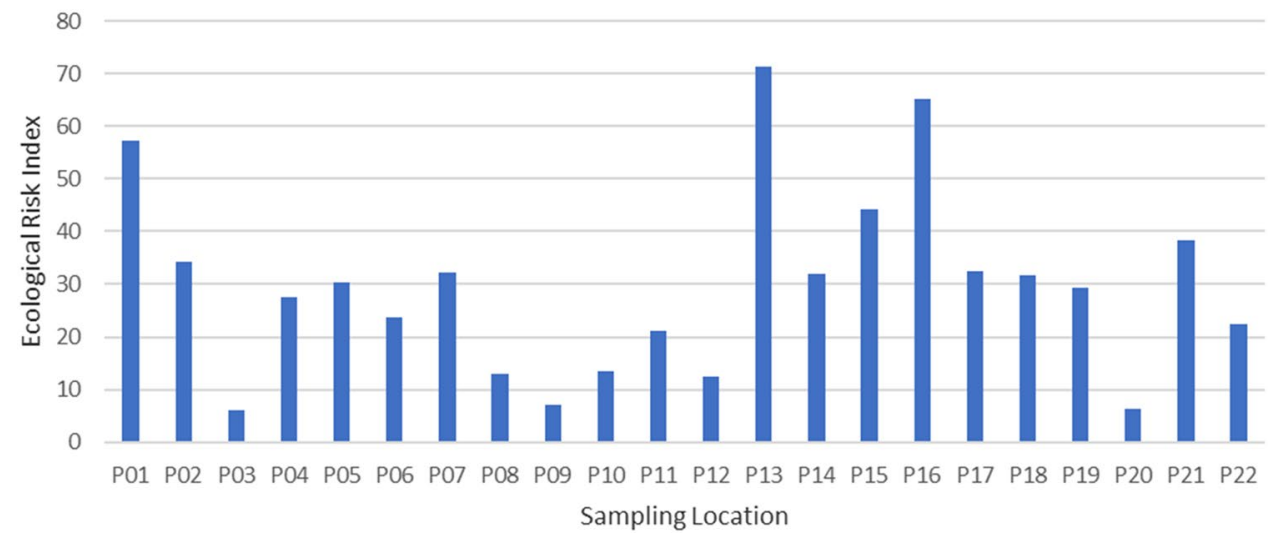




\section{Conclusion}

Concentrations of heavy metals in the Lake Chilwa catchment in southern Malawi were measured, and the associated ecological risk was determined. Highest concentrations were observed in the lower catchment, within the wetland areas that are dominated by rice and maize fields, while lowest values were observed from upland soils located in the mountain areas. Concentrations from all sampling locations were well below the threshold limits by USEPA guidelines. Correlation analysis and principal component analysis revealed that anthropogenic activities constitute the main sources of the metals to the soils. The ecological risk index showed levels ranging from low risk to moderate environmental and human health risk. It is important to note that heavy metals are persistent and bioaccumulate and magnify in organisms high in the trophic levels, causing irreparable damage. It is therefore imperative to monitor the levels and apply all necessary precautionary measures to manage the levels within acceptable limits for the sustainable utilization of the catchment.

Acknowledgements The authors are thankful to Envirotec and the Universities of Malawi and Tubingen for the provision of funds and laboratory facilities. We also acknowledge the financial and technical assistance from F. Schrenk, T. Bromage and M. Bauchle.

\section{Compliance with ethical standards}

Conflict of interest The authors declare no conflict of interest.

\section{References}

1. Mungai TM, Owino AA, Makokha VA, Gao Y, Yan X, Wang J (2016) Occurrences and toxicological risk assessment of eight heavy metals in agricultural soils from Kenya, Eastern Africa. Environ Sci Pollut Res 23(18):18533-18541

2. Yabe J, Ishuzuka M, Umemura T (2010) Current levels of heavy metal pollution in Africa. J Vet Med Sci 72(10):1257-1263

3. El Nemr A, Khaled A, Moneer AA, El Sikaily A (2012) Risk probability due to heavy metals in bivalve from Egyptian Mediterranean coast. Egypt J Aquat Res 38(2):67-75

4. Ahaneku IE, Sadiq BO (2014) Assessment of heavy metals in Nigerian agricultural soils. Pol J Environ Stud 23(4):1091-1100

5. Tenai B, Mbaria JJ, Muchemi G, Jansen R, Kotze A, Naidoo V, Gitau $F$ (2016) Assessment of heavy metals concentration in water, soil sediment and biological tissues of the lesser flamingos in four eastern rift valley lakes. Afr J Environ Sci Technol 10(6):162-166

6. Mahabadi HM, Ramroudi M, Asgharipour MR, Rahmani HR, Afyuni M (2020) Evaluation of the ecological risk index (Er) of heavy metals (HMs) pollution in urban field soils. SN ApplSci 2(8):1420. https://doi.org/10.1007/s42452-020-03219-7

7. Clark JHA, Tredoux M, Van Huyssteen CW (2015) Heavy metals in the soils of Bloemfontein, South Africa: concentration levels and possible sources. Environ Monit Assess 187(7):439
8. Ikenaka Y, Nakayama SMM, Muzandu K, Choongo K, Teraoka H, Mizuno N, Ishizuka M (2014) Heavy metal contamination of soils and sediments in Zambia. Afr J Environ Sci Technol 4(11):109-128

9. Opaluwa O, Aremu M, Ogbo L, Abiola K, Odiba I, Abubakar M, Nweze N (2012) Heavy metal concentrations in soils, plant leaves and crops grown around dump sites in Lafia Metropolis, Nasarawa State Nigeria. Pelagia Research Library 3(2):780-784

10. Sulaiman FR, Ibrahim NH, Syed Ismail SN (2020) Heavy metal $(\mathrm{As}, \mathrm{Cd}$, and $\mathrm{Pb}$ ) concentration in selected leafy vegetables from Jengka, Malaysia, and potential health risks. SN Appl Sci 2(8):1430. https://doi.org/10.1007/s42452-020-03231-x

11. Musa JJ, Mustapha HI, Bala JD, Ibrahim YY, Akos MP, Daniel ES, Kuti IA (2017) Heavy metals in agricultural soils in Nigeria: a Review. Arid Zone J Eng, Technol Environ 13(5):593-603

12. Kumwenda S, Tsakama M, Kalulu K, Kambala C (2012) Determination of biological, physical and chemical pollutants in mudi river, Blantyre, Malawi. J Basic Appl Sci Res 2(7):6833-6839

13. Chidya RCG, Sajidu SMI, Mwatseteza JF, Masamba WRL (2011) Evaluation and assessment of water quality in Likangala River and its catchment area. Phys Chem Earth 36(14-15):865-871

14. Kamzati LL, Kaonga CC, Mapoma HWT, Thulu F, Abdel-dayem SAJAH, Sakugawa (2019) Heavy metals in water, sediment, fish and associated risk from an endorheic lake located in southern Africa. Int J Environ Sci Technol 17(1):253-266

15. Mussa C, Biswick T, Changadeya W, Junginger A, Vunain E (2019) Levels and spatial distribution of heavy metals in lake Chilwa catchment Southern Malawi. ChemSearch J 10(2):66-73

16. Kaonga CC, Monjerezi M (2012) Periphyton and earthworms as biological indicators of metal pollution in streams of Blantyre City, Malawi. In: Balkis N (ed) Water pollution. InTech Open Access, Croatia, pp 1-22

17. Hakanson $L$ (1980) An ecological risk index for aquatic pollution control, a sedimentological approach. Water Res 14(8):975-1001

18. USEPA (2010) Land application of biosolids for home vegetable gardens. USEPA clean water act title 40 , section 503.13. https:// ecfr.gpoaccess.gov

19. Malan M, Müller F, Cyster L, Raitt L, Aalbers J (2015) Heavy metals in the irrigation water, soils and vegetables in the Philippi horticultural area in the Western Cape Province of South Africa. Environ Monit Assess 187(1):1-8

20. Gimeno-García E, Andreu V, Boluda R (1996) Heavy metals incidence in the application of inorganic fertilizers and pesticides to rice farming soils. Environ Pollut 92(1):19-25

21. Pullanikkatil D, Palamuleni L, Ruhiiga T (2015) Impact of land use on water quality in the Likangala catchment, southern Malawi. Afr J Aquat Sci 40(3):277-286

22. Chen F, Pu L (2007) Relationship between heavy metals and basic properties of agricultural soils in Kunshan County. Soils 39:291-296

23. Zimakowska-Gnoińska D, Bech J, Tobias FJ (2000) Assessment of the heavy metal pollution effects on the soil respiration in the Baix Llobregat (Catalonia, NE Spain). Environ Monit Assess 61(2):301-313. https://doi.org/10.1023/A:1006105329210

24. Han FX, Banin A, Su Y, Monts DL, Plodinec MJ, Kingery WL, Triplett GE (2002) Industrial age anthropogenic inputs of heavy metals into the pedosphere. Naturwissenschaften 89(11):497504. https://doi.org/10.1007/s00114-002-0373-4

25. Kim KH, Kim SH (1999) Heavy metal contamination of agricultural soils in central regions of Korea. Water Air Soil Contam 111:109-122

26. Wilcke W, Krauss M, Kobza J (2005) Concentrations and forms of heavy metals in Slovak soils. J Plant Nutr Soil Sci 168(5):676-686. https://doi.org/10.1002/jpln.200521811

27. Jean-Philippe SR, Labbé N, Franklin JA, Jonson A (2012) Detection of mercury and other metals in mercury contaminated soils 
using mid-infrared spectroscopy. Proc Int Acad Ecol Environ Sci 2(3):139-149

28. Prajapati SK, Meravi N (2014) Heavy metal speciation of soil and Calotropis procera from thermal power plant area. Proc Int Acad Ecol Environ Sci 4(2):68-71

29. Sayyed MRG, Sayadi MH (2011) Variations in the heavy metal accumulations within the surface soils from the Chitgar industrial area of Tehran.Proc Int Acad Ecol Environ Sci 1(1):36-46

30. Sekabira K, Origa HO, Basamba T, Mutumba G, Kakudidi E (2010) Assessment of heavy metal pollution in the urban stream sediments and its tributaries. Int J Environ Sci Technol 7(3):435-446

31. Benson NU, Anake WU, Etesin UM (2014) Trace metals levels in inorganic fertilizers commercially available in Nigeria. J Sci Res Reports 3(4):610-620

32. Xue H, Nhat PH, Gächter R, Hooda PS (2003) The transport of Cu and $\mathrm{Zn}$ from agricultural soils to surface water in a small catchment. Adv Environ Res 8(1):69-76
33. Codling EE (2009) Effect of flooding lead arsenate-contaminated orchard soil on growth and arsenic and lead accumulation in rice. Commun Soil Sci Plant Anal 40(17-18):2800-2815

34. Morrell JJ, Keefe D, Baileys RT (2010) Copper, zinc, and arsenic in soil surrounding douglas-fir poles treated with ammoniacal copper zinc arsenate (ACZA). J Environ Qual 32(6):2095

35. Duruibe JO, Ogwuegbu MOC, Egwurugwu JN (2007) Heavy metal pollution and human biotoxic effects. Int J Phys Sci 2:112-118

Publisher's Note Springer Nature remains neutral with regard to jurisdictional claims in published maps and institutional affiliations. 